EGU2020-19152

https://doi.org/10.5194/egusphere-egu2020-19152

EGU General Assembly 2020

(c) Author(s) 2020. This work is distributed under

the Creative Commons Attribution 4.0 License.

\title{
Solar Energy and the Water, Energy and Food Nexus: Petrolina- Juazeiro Case Study, Brazil
}

Erica Ferraz de Campos ${ }^{1}$, Pieter van Oel ${ }^{2}$, and Enio Bueno Pereira ${ }^{1}$

${ }^{1}$ INPE (Brazilian National Institute for Space Research) - CCST (Earth System Science Center)

${ }^{2}$ Wageningen University, Wageningen, The Netherlands

Water, energy and food are essential resources for society. Their integrated management, based on synergies and trade-offs, is determinant to attend the demand in long-term. Petrolina and Juazeiro are cities in Brazilian semiarid where coexist: the Sobradinho hydropower $\left(4,214 \mathrm{~km}^{2}\right.$ reservoir) and a fruit production center of $223 \mathrm{~km}^{2}$, for Brazilian and international markets. Both activities depend on São Francisco River and Sobradinho reservoir. Although the water demand from Sobradinho Reservoir is intense - around 1 billion $\mathrm{m}^{3}$, hydropower generation prevailed as a priority during the dry period 2012-2017. As the National Water Agency (ANA) maintained the reservoir outflow in rates above the water stream inflow, the reservoir was led to its minimum levels. The water scarcity during these years caused conflicts as it reduced hydroelectricity generation while put in risk the fruit production. Since solar irradiation is abundant in this region, solar power plants is figuring as a renewable energy alternative for the national grid. An increasing number of solar projects in this region are being approved in national auctions of electric energy expansion. Moreover, a floating photovoltaic power plant is already being tested in the Sobradinho reservoir. Therefore, the research analyses scenarios of water management if floating solar panels had been adopted in complementarity to hydroelectricity from 1999 and 2018, when very wet and very dry periods occurred. The software Water Evaluation and Planning (WEAP) is used to model the scenarios. Results are represented in water, energy and food safety indicators to identify the strategies of integrated resource management to target SDGs 6, 7 and 12. 